\title{
Correlation Analysis Among Innovation, Risk-taking, Competitive Aggressiveness, and Proactiveness on Com- pany Performance in the Covid-19 Situation
}

\author{
Bertha Silvia Sutejo $^{1 *}$, Marwin Antonius Rejeki Silalahi ${ }^{2}$
}

\author{
${ }^{1}$ University of Surabaya, Surabaya, Indonesia \\ ${ }^{2}$ University of Surabaya, Surabaya, Indonesia \\ *Corresponding author. Email: bertha@staff.ubaya.ac.id
}

\begin{abstract}
This research originated from the Covid-19 pandemic that began in February 2020. Since the Covid-19 pandemic, the Indonesian economy has experienced a significant decline, especially the MSMEs in Indonesia, so the authors are interested in examining the correlation among innovation, risk-taking, competitive aggressiveness, and proactiveness on company performance. This study uses a sample of MSMEs domiciled in Surabaya. This research method was carried out using purposive sampling by distributing questionnaires through the Google form application. This study uses classical assumption tests (normality test, multicollinearity test, and heteroscedasticity test) and paired sample test. This study's results are that innovation, risk-taking, competitive aggressiveness, and proactiveness variables have a strong effect on Company Performance. Research results are in line with previous research (Khotimah \& Fiati 2013, Alimudin 2013, Ismanto 2016, Haryono \& Marniyati 2017).
\end{abstract}

Keywords: Innovation, Risk-taking, Aggressiveness, Proactiveness.

\section{INTRODUCTION}

Indonesia is a country whose economy is growing, and most of the economy is supported by Micro, Small, and Medium Enterprises (MSMEs). MSMEs in Indonesia have been significantly growing. The Indonesian government welcomes this positively, as evidenced by the ratification of MSME regulations to ease entrepreneurs applying for official business permits. Moreover, Indonesia also lowered the Income Tax rate from $1 \%$ to $0.5 \%$ of sales turnover.

These days, MSMEs face a significant challenge of the Covid-19 pandemic situation that affects many countries worldwide, including Indonesia. Considering the Covid-19 pandemic situation in Indonesia, the researchers are interested in analyzing MSMEs, especially in Surabaya, whether they experience similar or different situations during the Covid-19 and the normal situation.
Discussing MSMEs cannot be separated from corporate entrepreneurship is carried out to promote entrepreneurial behavior in an organization. This applies basic management skills while adopting a behavior style that challenges bureaucracy and encourages. Entrepreneurship indeed requires basic management skills. In conducting business activities, corporate entrepreneurship bias is inseparable from innovation, proactivity, risk-taking, and competitive aggressiveness.

Human resources are essential factors for MSMEs. Education, training, experience, and mentoring are important factors related to human resource development. According to Parker (2000) in Belschak et al. (2010), proactive behavior is characterized as anticipatory, future or change-oriented, active, self-initiated, and persistent work behavior. For this reason, proactive behavior, especially for MSMEs, is very important in developing a more significant business and researchers be 
lieve that proactive behavior is closely related to financial performance.

According to Hartini (2012), innovation will result in quality products, where innovation itself is the development of an idea that is applied in the forms of a new product, or model, or design. A high-quality product will increase the company's competitive advantage, which has an impact on company performance. Risk-taking also influences MSMEs' financial performance because, according to the risk management guidelines for small businesses (Faizal et al. 2020), which the Global Risk Alliance organization manages, risks for small businesses include financial, organizational, legality, market, security, strategic, technical, criminal, reputation, service, project, management, and technology. These risks relate to one another and will affect the financial performance of small businesses. Apart from risk-taking, intense competition among MSMEs can also be a factor that affects the company's financial performance. Competitive aggressiveness relates to how the company thinks about the future, in this case, the long term for the next 5 to 10 years. Competitive advantages are low cost, product differentiation, focus on a specific market niche, and strong relationship with customers and suppliers.

Capital, marketing, and human resources are problems that exist in MSMEs. Entrepreneurial orientation and market orientation have a positive correlation with the inferential analysis of MSMEs. Meanwhile, Hartini's research (2012) reveals that global competition is closely related to innovation development for all companies.

Research by Kuratko et al. (2014) argues that top management support, work policy/autonomy, reward/reinforcement, time availability, and organizational boundaries are essential factors in entrepreneurial behavior.Conducive entrepreneurial behavior will lead to good company performance. In his article, Kuratko et al. (2014) introduce the Corporate Entrepreneurship Assessment Instrument (CEAI) as a diagnostic tool used to assess managers' perceptions of five criti- cal dimensions for creating an entrepreneurial/innovative environment. This instrument indicates that companies can successfully implement innovative strategies and highlight areas of the internal work environment that should focus on sustainable development efforts.

The research results by Belschak et al. (2010) show that different attitudes can simulate various forms of proactive behavior. While the strongest prosocial form of proactive (i.e., organizational and interpersonal) behavior is associated with team commitment, self-focus, or personal career-oriented proactive behavior that is primarily associated with career commitment. In addition, this is in line with the literature on commitment, which states that attachment to specific targets increases behavior that focuses on achieving goals and the success of these targets (Ellemers et al., 1998 in Belschak et al. 2010). Team commitment is more closely related to proactive (even organizationfocused) behavior than to organizational commitment. That seems to be in line with research on commitment showing that attachment to a more proximal and lower focus, such as a workgroup, may be more prominent to employees than engagement, at a more distal and higher level, such as organization (Riketta \& van Dick 2005 in Belschak et al. 2010).

Khotimah (2013) states that an e-business model can increase the competitive advantage of pottery MSMEs in the Mayong area of Jepara Regency. In the e-business model, there are two business processes managed, namely internal business processes (dealing with businesses in the pottery industry) and external business processes (selling products to consumers). Khotimah's research demonstrates that innovation will indirectly affect the financial performance of MSMEs. Ismanto (2016) also states that management ability, business strategy, and market orientation have a positive and significant influence on financial performance at SMEs Tenun Ikat Troso Jepara.

Alimudin (2013) shows entrepreneurial orientation has a positive and significant ef- 
fect on sustainability's competitive advantage. Entrepreneurial orientation has no significant effect on the trade sector of MSMEs (retailers of consumer goods) in Surabaya. The competitive advantage of sustainability has a significant and positive effect on marketing performance. Therefore, through the sustainable competitive advantage, entrepreneurial orientation significantly affects the trade sector of MSMEs (retailers of consumer goods) in Surabaya. From this research, it can be concluded that competitive aggressiveness is closely related to the performance of MSMEs. MSMEs' competitive advantage is not influenced by innovation, intellectual knowledge, and best practices.

Meanwhile, external environmental factors, including regular competition, newcomers, and substitute products, affect MSMEs' competitive advantage. The research results by Faizal et al. (2020) in apple cider producers, MSMEs have a risk-lover behavior towards new technology to support their business performance. From several previous studies, the researchers want to examine the difference between the independent and the dependent variables so that the following hypothesis can be drawn:

$\mathrm{H} 1$ : There is a relationship and the influence of innovation on company performance.

$\mathrm{H} 2$ : There is a relationship and the influence of risk-taking on company performance.

H3: There is a relationship and the influence of proactiveness on company performance.

$\mathrm{H} 4$ : There is a relationship and the influence of competitive aggressiveness on company performance.

\section{RESEARCH METHODS}

This study applied a purposive sampling method, where the researchers determined the sample based on specific criteria. The criteria are MSMEs that run their business in Surabaya and have run their business for more than one year. As this research was conducted during the Covid-19 pandemic, the questionnaires were distributed via
Google form and WhatsApp to MSMEs in Surabaya.

This study used primary data to carry out a classical assumption test, the normality test, multicollinearity, heteroscedasticity test, and autocorrelation test. Afterward, it was followed by a paired sample test to determine whether there are significant differences among innovation, risk-taking, proactiveness, and competitive aggressiveness variables on financial performance.

\section{RESEARCH METHODS}

Firstly, the classical assumption test is carried out before doing the difference test and the f-test. The first classical assumption test is the normality test. In Table 1 , the results of the normality test use the One-Sample Kolmogorov-Smirnov Test, which is seen from the sig (2-tailed) value of 0.070 , where the sig (2-tailed) value in this study is better, in above $5 \%$ so that the variables of innovation, risk-taking, proactiveness, competitive aggressiveness, and financial performance in this study are declared normal.

Table 1 . Normality Test Results

\begin{tabular}{lll} 
Normal Parameters & Mean & 154 \\
& & 0.0000 \\
& $\begin{array}{l}\text { Std Devia- } \\
\text { tion }\end{array}$ & 7.5657 \\
Most Extreme Differ- & Absolute & 0.100 \\
ences & & \\
& Positive & 0.071 \\
& Negative & -0.100 \\
Test Statistic & & 0.100 \\
Asymp. sig (2-tailed) & & 0.070 \\
\hline
\end{tabular}

Source: SPPS Version 25

The second classical assumption test is the multicollinearity test. In Table 2, the multicollinearity test results use the tolerance and VIF values. If the VIF value is less than 10 and the tolerance is more significant than 0.01 , then there is no multicollinearity. In this study, the VIF value obtained is less than 10 and tolerance greater than 0.01 . Thus, this research model does not have collinearity among innovation, risk-taking, pro- 
activeness, competitive aggressiveness, and financial performance variables.

\begin{tabular}{lcl} 
Table 2 Multicollinearity Test Results & \\
\hline Variable & Colerance & VIF \\
& & \\
Risk-Taking & 0.429 & 2.330 \\
Proactiveness & 0.413 & 2.422 \\
Comp. Aggressiveness & 0.681 & 1.469 \\
Innovation & 0.626 & 0.1598
\end{tabular}

Source: SPPS Version 25

Furthermore, the third classical assumption test is heteroscedasticity. The results of the heteroscedasticity test use a scatterplot, where if the dots on the scatterplot spread out, the dot spread also does not form a pattern, then the research model is declared no heteroscedasticity occurs. These research modelresults are free from heteroscedasticity because the scatterplot's dots are spread out and do not form a pattern.

Table 3 Difference Test Results

\begin{tabular}{lccl}
\hline & $\begin{array}{l}\text { Paired Sample Test } \\
\text { Df }\end{array}$ & $\begin{array}{ll}\text { Correlation } \\
\text { Risk-Kin }\end{array}$ & $\begin{array}{l}\text { Sig(2- } \\
\text { ntailed) }\end{array}$ \\
Proactive-Kin & 154 & 0.598 & 0.000 \\
Competitive-Kin & 154 & 0.620 & 0.000 \\
Innovation-Kin & 154 & 0.309 & 0.000 \\
\hline Sources: SPPS Version 25 & & 0.000 \\
\hline
\end{tabular}

Sources: SPPS Version 25

After the classical assumption test is carried out, in Table 3, a different test is carried out to see the relationship among innovation, risk-taking, proactiveness, and competitive aggressiveness variables with financial performance. Each independent variable affects or does not affect the dependent variable. If the test results are sig $<0.05$, then there is an influence between one variable and another. This study also reveals that the risk-taking variable has a correlation value of 0.598 on financial performance, the proactive variable has a correlation value of 0.620 , the innovation variable has a correlation value of 0.599 on financial performance, of the three variables, are correlated with 0.50 , meaning that the three variables have a correlation value strongly correlated with financial performance. While the competitive aggressiveness variable has a correlation value of 0.309 on financial performance, although the com- petitive aggressiveness variable does not have a strong correlation with financial performance, the variables of competitive aggressiveness, risk-taking, proactivity, and innovation have an effect on financial performance because the sig value is 0.000 $<0.05$

Based on the results of the study using the paired sample test, the results obtained are in line with Khotimah \& Fiati (2013), Alimudin (2013), Ismanto (2016), and Haryono \& Marniyati (2017) that reveal innovation, risk-taking, proactivity, and competitive aggressiveness have a relationship and influence on company performance, whereas Hartini's (2012) research is not in line with this study, where innovation has no effect on company performance.

\section{CONCLUSION}

This study's results are variables of risktaking, proactiveness, competitive aggressiveness, and innovation have a strong relationship and influence on company performance. That is by following the concept of measuring company performance, where company performance cannot be separated from internal and external matters of the company. Internal company factors include the activeness of human resources in making changes to any innovation that supports the company's operations. The more these innovations have a positive effect, the company's performance will increase by itself. The company's external factors include the risks inherent in the business and the influence of the business environment. The company's external factors also include competition between other companies. The more comfortable the industry is for new entrepreneurs to enter, the tighter the competition in the industry will be. Besides, we can see that many previous researchers tested the effect of financial performance with the variables of innovation, proactivity, competitive aggressiveness, and risk-taking. 


\section{REFERENCES}

Alimudin, A. 2013. Pengaruh Orientasi Wirausaha Terhadap Keunggulan Bersaing Berkelanjutan san Kinerja Pemasaran Usaha Kecil Sektor Perdagangan (Consumer Goods) di Kota Surabaya. Jurnal FEB UNSOED 3(1): 1- 10.

Kuratko, D.F., Hornsby, J.F. \& Covin, J.G. 2014. Diagnosing a Firm's Internal Environment for Corporate Entrepreneurship. Business Horizons 57(1):37-47.

Faizal, F., Rayesa, N.F. \& Retnoningsih. D. 2020. Perilaku Pengusaha UMKM Olahan Apel Terhadap Resiko Usaha dan Dampaknya terhadap Pertumbuhan UMKM. Jurnal Agriekstensia, 19(2): $104-113$.

Belschak, F.D. \& Den Hartog, D.N. 2010. Pro-self, Prosocial, and Pro-organizational Foci of Proactive Behavior: Differential Antecedents and consequences, Journal of Occupational and Organizational Psychology 83(2): 475-498.

Hartini, S. 2012. Peran Inovasi: Pengembangan Kualitas Produk dan Kinerja Bisnis. Jurnal Manajemen Dan Kewirausahaan 14(1): 82-88.

Haryono, T. \& Marniyati, S. 2017. Pengaruh Market Orientation, Inovasi Produk, dan Kualitas Produk Terhadap Kinerja Bisnis dalam Menciptakan Keunggulan Bersaing. Jurnal Bisnis \& Manajemen, 17(2):51-68.

Ismanto, H. 2016. Analis Kinerja Keuangan UMKM Tenun Ikat Troso Jepara. Jurnal Economia 12(2): 159-166.

Khotimah, T. \& Fiati, R. 2013. Peningkatan Keunggulan Kompetitif pada UMKM Gerabah Melalui Model E- Business. Jurnal SIMETRIS, 3(1): 31-40. 